\title{
CESÓ LA HORRIBLENOCHE: EL COLOR DOCUMENTAL DE “EL BOGOTAZO”
}

\author{
THE HORRIBLE NIGHT CEASED: THE \\ DOCUMENTARY COLOR OF "EL BOGOTAZO" \\ CESSOU A HORRÍVEL NOITE: A COR \\ DOCUMENTAL DO "BOGOTAZO"
}

Por:

Yamid Galindo Cardona ${ }^{1}$

Historiador de Cine

Investigador y profesor universitario yamid74@gmail.com

A María Fanny \& Bernardo

Mis padres.

Resumen: Este artículo analiza el documental Cesó la Horrible Noche (2013) de Ricardo Restrepo, su impacto como obra del patrimonio audiovisual colombiano que presenta otros momentos del 9 de abril de 1948. Las imágenes de "El Bogotazo" siempre tendrán como eje central la figura de Jorge Eliecer Gaitán. La fotografía, las películas documentales o de ficción, la música, las memorias literarias, las investigaciones académicas, suman a un tema que se ha convertido en género de análisis que involucra nuestra historia política nacional. A partir de este importante documental sobre una visión personal de "El Bogotazo", a través del archivo casero a color, se entrega un balance del hecho histórico en el contexto cinematográfico colombiano, centrándose posteriormente en las imágenes, el montaje y su representación en el proceso de memoria y olvido ligado a otros puntos de análisis.

Palabras clave: Cine Documental Colombiano, El Bogotazo, Historia de Colombia, Memoria, Roberto Restrepo, Violencia. 
Abstract: This paper analyzes Ricardo Restrepo's documentary Cesó la Horrible Noche (The Horrible Night ceased) -2013- and its impact as a work of Colombian audiovisual heritage, as it presents other moments of April $9^{\text {th }}$ 1948. The images of "El Bogotazo" will always have as main axis the figure of Jorge Eliecer Gaitán. Photography, documentary or fiction films, music, literary memoirs, and academic research add to a topic which has become an analysis genre that involves Colombian political history. Based on this important documentary about a personal vision of "El Bogotazo", made through the home-made archives in color, the paper presents a balance of the historical fact inside the Colombian cinematographic context, and then to focus on the images, the staging and its representation in the memory and oblivion process bound to other points of analysis.

Keywords: Colombian Documentary Cinema, El Bogotazo, Colombian History, Memory, Roberto Restrepo, Violence.

Resumo: Este artigo analisa o documental Cessou a horrível noite (2013) de Ricardo Restrepo e o seu impacte como obra do patrimônio audiovisual Colombiano ao apresentar outros momentos de 9 de Abril de 1948. As imagens do "Bogotazo" sempre terão como eixo central a figura de Jorge Eliécer Gaitán tanto nos seus momentos transcendentais, quanto nos mais tristes, onde o povo participa ativamente. A fotografia, os documentários e os filmes de ficção, as músicas, as memórias literárias, as pesquisas feitas de natureza acadêmica, sumam para um tema que tem se convertido em gênero de analise que envolve a nossa história política nacional, pois o feito que transcendeu a capital Colombiana até as outras regiões do país, representadas pelas suas capitais, povoados de menor importância, e as zonas rurais, aquelas que seguiram suportando a Violência. A partir desse importante documentário sobre uma visão pessoal do "Bogotazo", através do arquivo caseiro com cor, fornece-se um resumo do feito histórico no contexto cinematográfico Colombiano, focando-se posteriormente nas imagens, a montagem, a sua representação no processo de memória e esquecimento unido a outros pontos de análise.

Palavras-chave: Cor, cinema documental Colombiano, o "Bogotazo", história da Colômbia, memória, Roberto Restrepo, Violência.

\section{Introducción}

Un estudioso de la imagen afirma que ésta, elemento de futuro y duración que tiene más de memoria y porvenir que quienes la observamos, no sobrevivirá. Sentencia directa para entender por qué la fascinación hacia a ellas, a su encuentro, análisis y reinterpretación; sumado a su sentencia que "la historia de las imágenes es una historia de objetos temporalmente impuros, complejos, sobredeterminados" (Didi-Huberman, 2006, p.26). En el estudio de caso que nos convoca, representado en el documental Cesó la Horrible Noche, el archivo fílmico perduró a su autor, contiene altas dosis de memoria histórica, utilizada en algunas circunstancias como instrumento político con una apuesta directa al futuro que nos espera, el del postconflicto. 
La obra de Ricardo Restrepo hace parte de esa categoría propuesta por Pedro Adrián Zuluaga para el cine documental colombiano denominado discurso oficial. La obra se ve inmersa en "la tentación de convertir al archivo en un fetiche, otorgándole una carga de prueba que en realidad no tiene, o de confundir la memoria - un hecho humano universal- con sus repositorios" (Zuluaga, 2015). Debate inmerso en el sentido y origen de realización de este trabajo, vinculado a una de las becas del Estado, y el supuesto uso que puede tener, incluyendo el montaje que hace el autor del archivo al poner, valorar y sobredimensionar algunos aspectos.

Se entrega a los lectores un balance del hecho histórico representado en el 9 de abril en el contexto cinematográfico colombiano, centrándose posteriormente en las imágenes, el montaje y su representación como proceso de memoria y olvido; lo anterior, en momentos cruciales para la historia social y política del país que todavía lleva el lastre de la denominada Violencia. Muchos colombianos tienen algo qué contar y el cine colombiano mucho qué mostrar, en este caso el documental de Ricardo Restrepo.

\section{El Bogotazo filmado}

En medio de las fotos blanco/negro, color y sepia que resguarda una depositaria familiar, se encuentra una que no corresponde al círculo afectivo, pero que, por su historia particular, tiene un significado de importancia mayúscula. Se trata de Jorge Eliecer Gaitán en su expresión más juvenil, a medio cuerpo, con traje de paño y cabello peinado hacia atrás con una tonalidad brillante que denota el uso de gomina.

La postal fotográfica es el primer recuerdo que tengo del líder liberal inmolado. El segundo recuerdo viene de la biblioteca doméstica con el libro de Arturo Álape El Bogotazo, Memorias del olvido, de 1983. Tenía como imagen en la sobrecubierta la escena del actor Edgardo Román protagonizando a Gaitán, y en posición de caída luego de recibir los impactos de bala de su asesino, en plena calle Séptima de la capital colombiana el 9 de abril de $1948^{2}$.

Retomando la portada del libro de Álape, puedo decir que el tercer recuerdo que me llega es la serie televisiva El Bogotazo, dentro del listado de obras de reconstrucción histórica llevadas a la pantalla por parte de Eduardo Lemaitre Televisión, en las décadas del setenta y ochenta del siglo pasado, en lo que conocimos como Revivamos Nuestra Historia; serie dirigida por Jorge Alí Triana, con guiones de Carlos José Reyes ${ }^{3}$.

La obra recrea los acontecimientos más importantes del 9 de abril desde el personaje central, y la institucionalidad política de los partidos tradicionales. Serie interesante, teniendo en cuenta las dificultades de representar las manifestaciones del pueblo enardecido y la transformación urbanística sufrida por la capital colombiana. Utiliza imágenes de los hechos del 9 de abril, y la voz en off del líder inmolado en algunos apartes, una constante en trabajos documentales sobre la temática. 


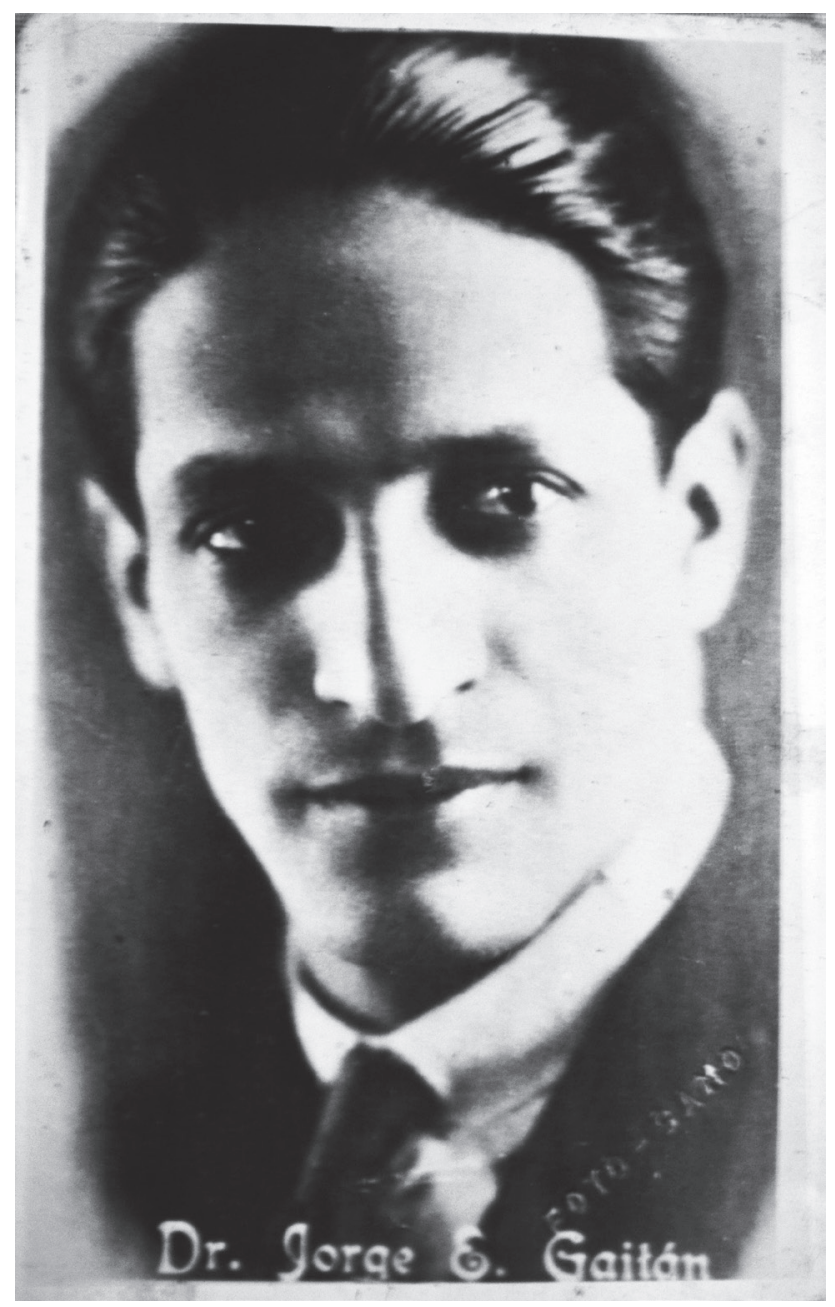

Figura 1. Jorge Eliecer Gaitán -Foto familiar-.

El cine no ha sido ajeno al tema, en Historia del Cine colombiano, Hernando Martínez Pardo comenta que la empresa Grancolombiana Films, de Marco Tulio Lizarazo, fue encomendada para filmar la Conferencia Panamericana a realizarse en abril de 1948, ante lo cual contrató dos productoras extranjeras, una italiana y la venezolana Bolívar Films. Prosigue el autor anotando que Lizarazo no se quedó sin imágenes del 9 de abril, logró comprar una copia de un documental elaborado por visitantes cubanos que habían llegado interesados en la Conferencia Panamericana y habían documentado los hechos de El Bogotazo. Pero estas imágenes tendrían un destino particular al ser usadas en una fallida apología documental al General Gustavo Rojas Pinilla, quien era el actor principal de una cinta que mostraba el antes, durante y después de su Golpe de Estado. Esas imágenes compradas por Lizarazo a los cubanos, entraron en la edición de dicho documento fílmico, que lastimosamente no logró salir de su laboratorio de sonorización, devuelto a su director con mutilaciones. Más adelante Lizarazo prestó su trabajo a los líderes de la Anapo ${ }^{4}$ para sus campañas políticas, pero su resultado fue similar al del laboratorio de cine estatal: recorte y pérdida de imágenes (Martínez, 1978, pp. 178-179). 
El otro caso de importancia es el de Procinal -Promotora Cinematográfica Nacionalde Camilo Correa, mordaz crítico cinematográfico del periódico El Colombiano, convertido a cineasta, quien junto a Charles Riou -jefe de producción, adaptador, editor y guionista de la empresa-, les correspondió el 9 de abril bogotano:

[...] Correa estaba en Bogotá tomando material para el Noticiero: “Al oír que habían asesinado a Gaitán -narra C. Correa- tomé la cámara y salí sin pensar cómo iba ser aquello. Estuve en el centro filmando todo lo que veía, incendios, muertos, gente cargada con lo que había robado en los almacenes, el capitolio en llamas. En la Avenida Jiménez me encontré con uno de los camarógrafos de la compañía de cine venezolana que había traído Marco Tulio Lizarazo para filmar la Conferencia Panamericana. Se me acercó y me ofreció comprarme a diez dólares el pie, todo lo que había filmado. No se lo vendí, pero me contó que un gringo estaba comprando a trece dólares el pie de filmación. Después supe que el venezolano se había ido a Estados Unidos con el gringo. Jamás regresó. (Martínez, 1978, p. 184)

Riou, con otra cámara, estaba en el capitolio filmando aspectos de la reunión internacional, también para el Noticiero de la Procinal, afirma haber filmado catorce rollos en las calles del centro, en la Clínica Bogotá, en palacio y en el cementerio. Las anécdotas abundan en los dos relatos. Del material filmado se hizo un montaje exhibido en los cines, "después lo vendimos al gobierno - dice Correa- y otra parte se dañó en la terraza donde amontonaron todas las filmaciones cuando se liquidó Procinal” (Martínez, 1978, p. 185).

Las imágenes filmadas de El Bogotazo hacen parte de la memoria histórica convertida en patrimonio, usadas continuamente en trabajos documentales como material de apoyo. Además, la figura del líder liberal ya tenía ciertos precedentes como hombre público, digno de filmar para ubicar en los noticiosos tan en boga durante la mitad del Siglo $\mathrm{XX}$ colombiano, como complemento a la cinta central exhibida en nuestros teatros. También es necesario advertir que la Conferencia Panamericana, mediáticamente, tenía un grupo de operadores cinematográficos pendientes de tales reuniones, lo que posibilitó que al momento de los acontecimientos algunos se desplazaran al centro capitalino para captar imágenes. Por esto, además de Lizarazo, los venezolanos, Correa y Riou, debieron existir otros acuciosos testigos que bajo su ojo y lente captaron el desorden social, y tal vez viajaron a otros destinos con estas imágenes.

El cine colombiano no sería ajeno al tema de Jorge Eliecer Gaitán y El Bogotazo, mezcla de ficción y realidad. Inicialmente, la película Canaguaro de Dunav Kuzmanich, realizada entre 1978 y 1981, recrea la Violencia en los Llanos después del asesinato de Gaitán. Sobre la obra, Isabel Sánchez afirma que el guión fue elaborado a partir de una anécdota que resumía muchos de los problemas que querían plantear, el dirigido al periplo de un grupo guerrillero en busca de las armas que la dirección del partido Liberal les haría llegar en algún lugar cercano a la frontera con Venezuela (Sánchez, 1987, pp. 19,20). 


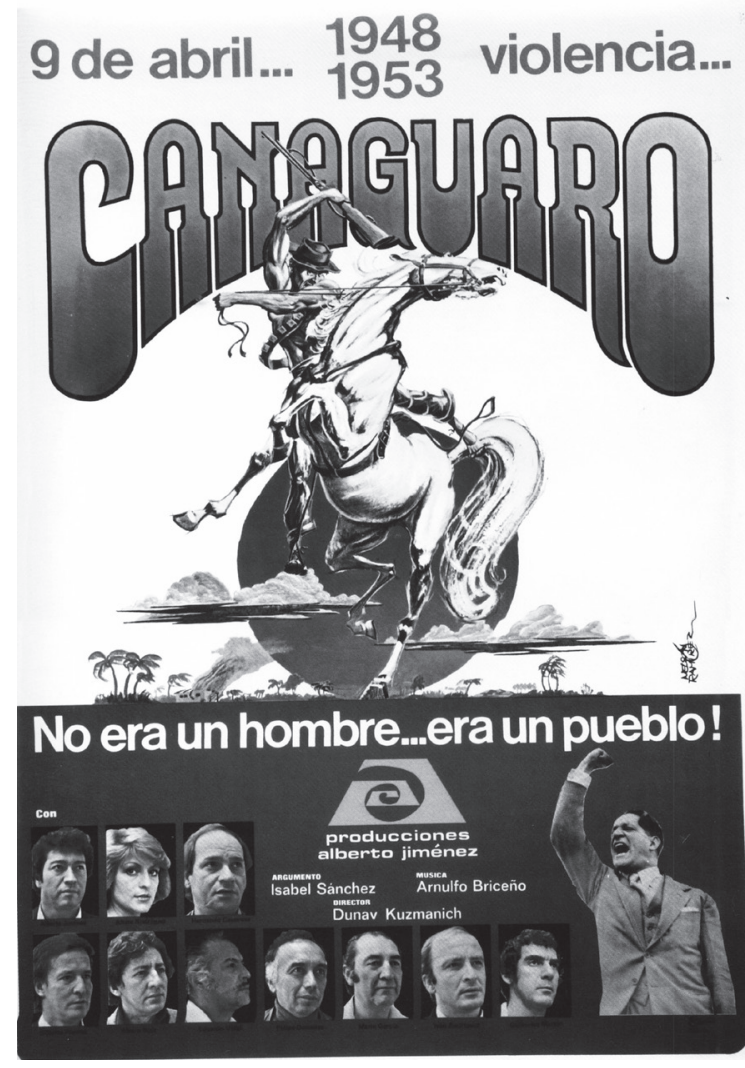

El segundo filme corresponde a la novela de Gustavo Álvarez Gardeazábal adaptada al cine por Francisco Norden, Antonio Montaña, Carlos José Reyes y Dunav Kuzmanich, titulada Cóndores no Entierran Todos los Días. Fue estrenada en 1984, centra su historia en el personaje León María Lozano, mejor conocido como el Cóndor, justiciero político vinculado al partido Conservador y a los denominados “pájaros". En medio de la vida de este personaje vallecaucano, se atraviesa el acontecimiento bogotano desde una pequeña ciudad de la provincia (Sánchez, 1987, pp.91-93).

Figura 3. Cóndores no entierras todos los días, Fuente: Carteles de largometrajes colombianos en cine 1925-2012, FPFC.
Figura 2. Canaguaro. Fuente: Carteles de largometrajes colombianos en cine 1925-2012, FPFC. 
La tercera película Confesión a Laura, dirigida por Jaime Osorio en 1990, recrea una historia entre dos personajes que viven en apartamentos diferentes pero en la misma calle. Contextualizada por el orden público de la ciudad luego de los disturbios del 9 de abril, y ante el peligro por francotiradores ubicados en los tejados, Santiago decide resguardarse en la casa de su vecina Laura, comenzando una serie de diálogos que convergen en una relación casi íntima, oculta, en sitio ajeno y con una vigilante constante, Josefina. Si la vida cotidiana de Bogotá y el país ha cambiado desde ese viernes a la 1:00 pm, la de los tres, separados por una calle, tendrá otro destino.

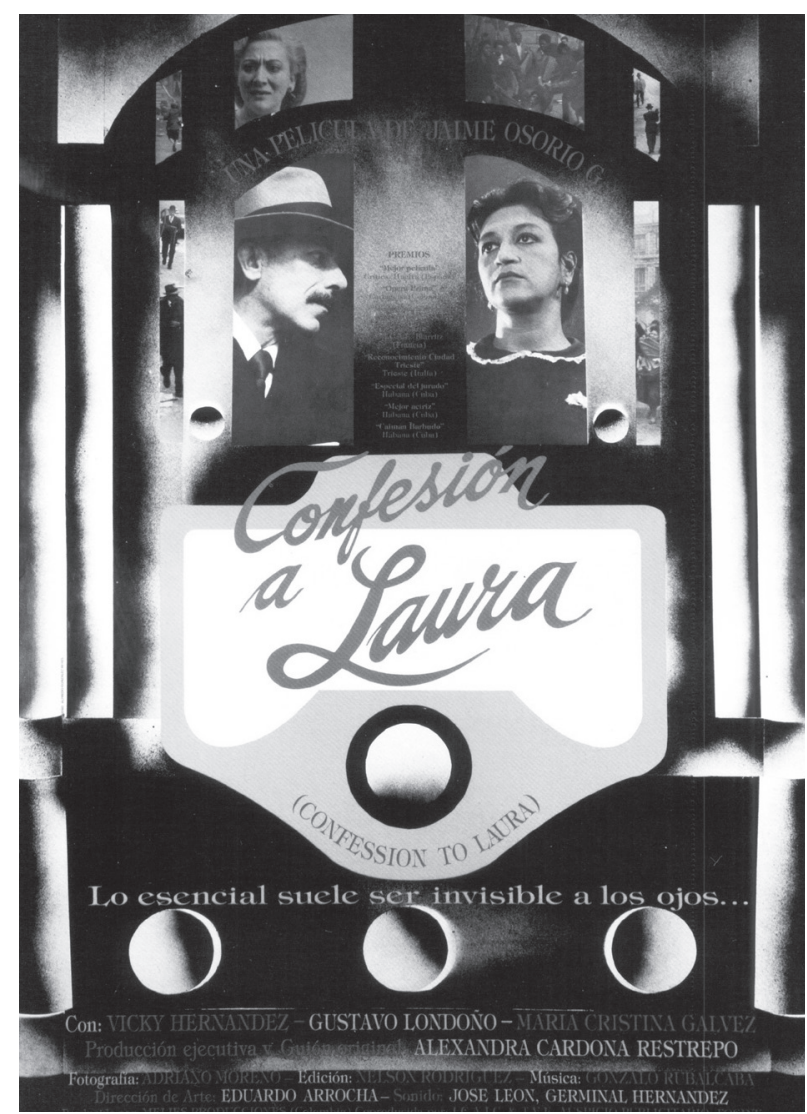

Figura 4. Confesión a Laura, Fuente: Carteles de largometrajes colombianos en cine 1925-2012, FPFC.

En el 2013 se estrenó en las pantallas colombianas la adaptación del libro de Miguel Torres “El Crimen del Siglo”, texto sobre la vida de Juan Roa Sierra, el supuesto asesino de Jorge Eliecer Gaitán. Por su parte, la película Roa, de Andrés Baiz, nos deja con la insatisfacción de una regular puesta en escena, la no convincente actuación y representación de Gaitán, y algunos rasgos distintivos de la personalidad de Roa que nos expone Torres, pero que al ser adaptados en el filme, quedan sin la "sustancia" debida para entender el personaje en función de su contexto histórico, y por el cual es recordado en medio de la maraña política, social, y violenta de los años cuarenta en Colombia. Jugando con el archivo fílmico, entremezclando los actores, podemos encontrarnos con imágenes del periodo, junto a algunas fotografías de Sady González que entran como conclusión a la par de los créditos. 


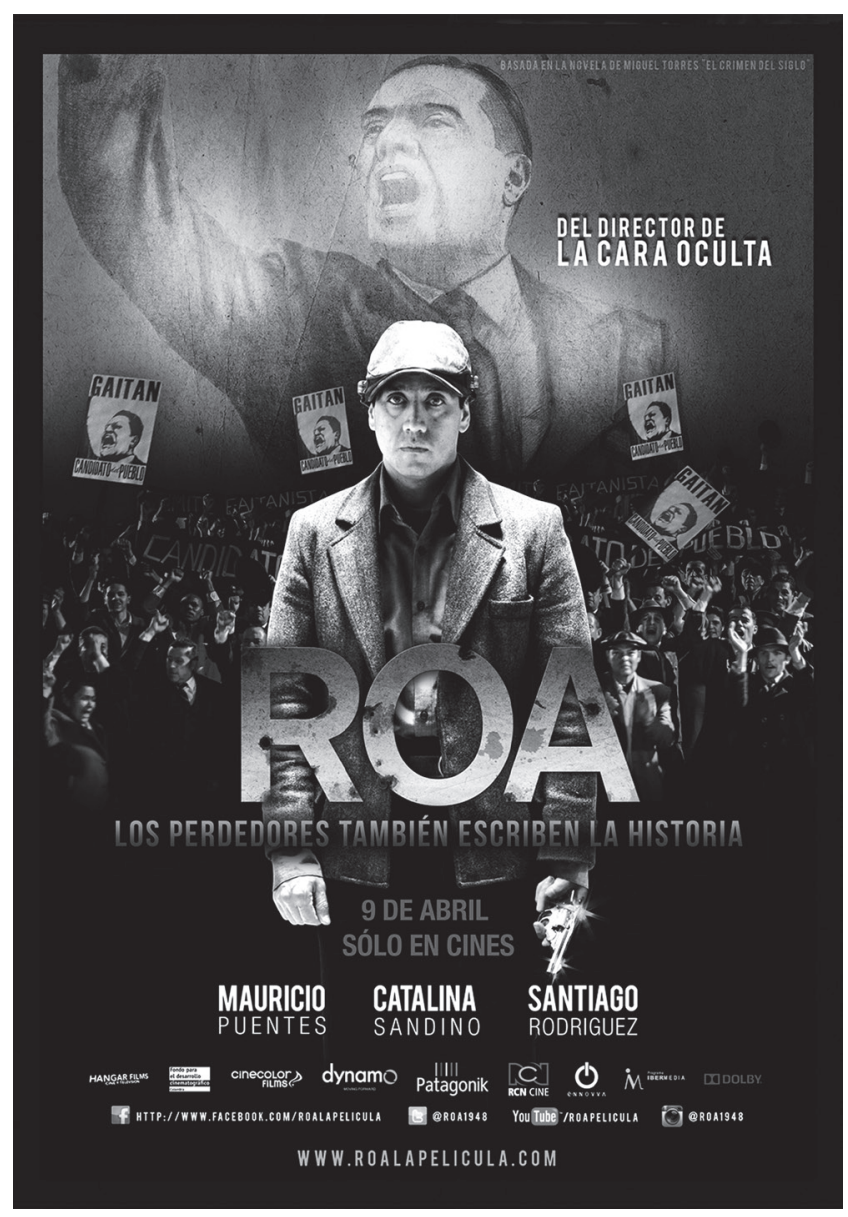

Figura 5..Afiche película Roa. Fuente: Proimágenes Colombia.

Con respecto al género documental, en 1998 María Valencia Gaitán -nieta del caudillorealiza Gaitán Sí, una recopilación biográfica importante que rescata los momentos más trascendentales en la vida de Jorge Eliecer Gaitán, con un hecho particular: su hija Gloria, entra en escena para contarnos algunos aspectos de su relación como hija, además de usar las escenas filmadas del líder, y su voz en los discursos. Un video familiar de escasos segundos que nos muestra a un Gaitán en pleno juego familiar con su hija, y una serie de testimonios a apropósito de los efectos suscitados en su trabajo político por el país. En el 2008, con motivo de los 60 años de su magnicidio, el canal Caracol, junto a The History Chanel, realizó El Bogotazo: La Historia de una Ilusión, documental que aprovecha la coyuntura nacional para ligarla con la situación vivida el 9 de abril de 1948 .

Además de los recursos audiovisuales, encontramos en nuestras universidades investigaciones que dan información sobre lo vivido en ese momento, algunas con referencias a la tradición oral y las fuentes periodísticas. En mi entorno familiar, el 9 de abril de 1948 salta en la discusión porque nuestros padres o abuelos vivieron el momento en el que todo el país un viernes en la tarde, sintió como el eco de una frase se transformaba en estallido, desilusión y tristeza: ¡Mataron a Gaitán! 


\section{El documental fílmico como memoria histórica}

Ver un documental significa entrar en un modo des-conocido interpretado por personajes con estilos narrativos influenciados por esquemas construidos con la experiencia de ver, observar, analizar, leer, y fundamentar una idea valiosa para su exhibición. Esto sucede por medio de un montaje efectivo, con temas variados que exponen la ciudad, el campo, mujeres, hombres, niños, ruinas, conflictos, desastres, noticias, violencias, personajes, archivos, olvidos, memorias, ciudadanos desconocidos, e innumerables temas que la vida cotidiana nos entrega en su pasado y presente.

Como explicación académica, el documental significa:

[...] montaje cinematográfico de imágenes visuales y sonoras propuestas como reales y no ficcionales. El film documental presenta casi siempre un carácter didáctico o informativo que intenta principalmente restituir las apariencias de la realidad, mostrar las cosas y el mundo tal y como son; el documental no sólo plantea el problema del universo de referencia. Concierne también a las modalidades discursivas, ya que puede adoptar las técnicas más diversas: film de montaje, cine directo, reportaje, actualidad, film didáctico, hasta film familiar. La evolución de las formas en el cine está presente para demostrar que las fronteras entre documental y ficción nunca son herméticas y que varían considerablemente de una época a otra y de una producción nacional a otra (Aumont, Marie, 2006, p. 67).

Realidad y ficción, conceptos que se ponen de manifiesto al momento de entrar en las latitudes del montaje en el documental, ¿qué tan manipulable puede resultar esa realidad?, ¿cómo se puede distorsionar y hacer creíble en el eje central de la obra? Preguntas directas que desembocan en nuevos escenarios de narración, donde la manipulación tiene sentido en el objetivo que busca el director al presentarnos unos registros y descubrir que los espectadores asumen los hechos representados como acciones verídicas en el marco de un contexto social que conoce ${ }^{5}$.

La memoria histórica de nuestro país transita por un camino difícil marcado por la Violencia política de mediados del siglo pasado, y el conflicto armado de largo aliento. En Colombia, las situaciones devenidas han posibilitado que desde la academia se entreguen obras de interés nacional para identificar las raíces de nuestros problemas con análisis antropológicos, artísticos, históricos y sociológicos. Así, el arte no es ajeno y se aproxima efectivamente a entregar una opinión responsable a través de diversas manifestaciones, como el cine documental.

Siguiendo el camino que nos traza Paul Ricoeur, encontramos en el archivo fílmico una operación significativa que se realiza cuando el testimonio es oralizado, escuchado y escrito. La comparación que hacemos con el documento cinematográfico, también es una lectura que realiza el historiador del cine: 
[...] A estos rasgos de escrituralidad que tiene en común con el relato, el testimonio añade rasgos específicos ligados a la estructura de intercambio entre el que lo da y el que lo recibe: en virtud del carácter reiterativo que le confiere el estatuto de la institución, el testimonio puede ser recogido por escrito, presentado, depositado. La deposición es, a su vez, la condición de posibilidad de instituciones específicas dedicadas a la recopilación, a la conservación, a la clasificación de un conjunto de documentos para la consulta por parte de las personas habilitadas para ello. El archivo se presenta así como un lugar físico que aloja el destino de esta especie de huella que, con todo cuidado, nosotros distinguimos de la huella cerebral y de la huella efectiva, es decir, la huella documental. Pero el archivo no es sólo un lugar físico, espacial; es también un lugar social. (2010, p.216)

Lo que reconocemos institucionalmente como depósito de archivos, fue posible por el intercambio, donación, compra de los estados para conservar la memoria escrita de su historia jurídica, institucional y ejecutiva; trasladada con el tiempo a otros escenarios de la vida cultural, convertida en patrimonio. Ajustándose en parte al principio básico de encuentro con una huella indiciaria para reconocer un hecho que merece su relación histórica, descriptiva, teórica y representativa.

Ricoeur culmina entregándonos otro paso, más dinámico, más especial, el del archivo como "un lugar social", premisa que podemos conectar con la posición de quien con una cámara fílmica se suma al escenario de un entorno cultural y cotidiano como la ciudad. En ella se capturan imágenes en movimiento que pasan de ser un momento personal de intención reportera, al resguardo del archivo familiar y que luego salen rescatadas, restauradas, transformadas y editadas con cierto montaje subjetivo. Analizando las posibilidades del uso del cine documental como documento histórico, apropiamos las reflexiones de Peter Burke, el cual considera "el testimonio del cine" como un relato más fluido con un "efecto realidad" o una "ilusión de realidad" (2005, p. 195). Nuestro análisis aborda el principio básico de un trabajo fílmico de trascendencia histórica por su significado social y político que marcó un período de la historia nacional, y que podemos ahondar a partir de la siguiente reflexión:

[...] Una vez más, el problema radica en evaluar esta modalidad del testimonio, en desarrollar un tipo de crítica de las fuentes que tenga en cuenta las características del medio, el lenguaje de la imagen en movimiento. Como ocurre con otros tipos de documentación, el historiador debe enfrentarse al problema de la autenticidad. Es preciso averiguar si una determinada película, o una escena de una determinada película ha sido rodada en directo, o ha sido fabricada en el estudio utilizando actores o maquetas. [...] En el caso de las películas, el problema de detectar las interpolaciones resulta especialmente arduo, dada la costumbre de recurrir el montaje y la relativa facilidad con la que pueden introducirse en una secuencia imágenes de lugares o acontecimientos distintos. (2005, p. 197) 
El problema de la autenticidad marca un efecto relevante en las imágenes que tenemos al frente como observadores; en este caso, con el documental Cesó la Horrible la Noche, tenemos una sensación particular de ver algo que conocemos, pero que lo encontramos diferente por el color con que nos entregan las imágenes, asumiéndolas con unas referencias directas de quien las edita y presenta con una marca precisa de filmaciones verídicas, resguardadas y asumidas como un simple acto de intervención ciudadana; pero "dada la importancia que tienen la mano que sujeta la cámara, y el ojo y el cerebro que la dirigen, convendría más bien hablar del realizador cinematográfico como historiador" (Burke, p. 201).

Para el trabajo que nos convoca el documental opera como dispositivo histórico que pone de manifiesto un acontecimiento de la historia social y política del país, desde el ojo observador de un ciudadano que tenía su cámara para el oficio casero y familiar, y que supo darle uso para atestiguar los estragos del centro de una ciudad en abril de 1948 .

\section{Cesó la Horrible Noche: El color documental de "El Bogotazo"}

Para la historia del cine colombiano es importante que los trabajos documentales se acerquen a actividades manifiestas de representación de nuestro pasado a través de los archivos, sobretodo si son desconocidos y traen otras perspectivas de visualización y narración. Ricardo Restrepo realiza un documental de corte histórico a partir de un registro personal de los hechos ocurridos el 9 de abril de 1948 a través de la mirada de su abuelo Roberto Luis Restrepo (1897-1956): "La película nace hace más o menos treinta años, cuando supe por primera vez que había un material realizado por mi abuelo, que era médico, material fílmico del 9 de abril del 48. Durante esos treinta años estuve buscándolo, y nunca lo encontré, sencillamente no se sabía dónde estaba, hasta que por fin, hace dos años, tuve la fortuna de encontrar 25 latas de 400 pies, 16 mm, y unas 100 bobinas de cien pies"6.

Al reflexionar sobre los archivos, Michele Lagny expone unos pasos esenciales que parecen básicos y se desarrollan instintivamente en el dispositivo del investigador; así, acomodándonos al proceso realizado por el documentalista colombiano, observamos que Restrepo fue tras las huellas de unos documentos fílmicos, los buscó y encontró; rescatando un testimonio que implicó un patrimonio conservado, refugio especial encuadrado en los espacios familiares de preservación (1997, p. 61).

Sobre la obra, el título, y su interlocutor activo, nos dice el director:

[...]Mi abuelo filmó en $16 \mathrm{~mm}$; hicimos un trabajo de restauración fílmica, limpiando el material, redigitalizando todo a HD. Fue un trabajo que hizo Kinolab, muy profesional, muy interesante ese proceso de digitalización. Es una película..., primero, el tono es muy personal, hablo yo con mi abuelo que no conocí, el escribió un diario, y entonces a ese diario se le da lectura con un actor que es Diego Trujillo. Es 
una labor muy intimista, pero como en cada película hay alrededor mucha gente: la productora Pathos Audiovisual, Señal Colombia que es coproductor, la gente de Kinolab que hizo el trabajo de recuperación fílmica. A Aarón Moreno que hizo la música original... se le ocurrió que había cesado la horrible noche en este país lleno de violencia y de injusticia. La película recoge todos esos 65 años desde que mi abuelo empezó a filmar en 1935 hasta ahora, y nos seguimos preguntando lo mismo ¿Cesó la horrible noche? O no ha cesado... La presenté en familia, la catarsis no fue tanto mía, sino de mi señor padre, se conmovió infinitamente, él nunca había visto las imágenes del abuelo, de su padre, tampoco lo había visto en esta forma. ${ }^{7}$

Entrando en la visualización de la obra, se identifican los siguientes focos de análisis y descripción, partiendo de una mirada particular de encuentro con la obra y su contenido, lo que he denominado "partes esquemáticas divididas por el cuadro oscuro" divididas en: Cita introductoria; movimiento en la plaza central; repaso por la historia decimonónica; descubriendo la memoria fílmica; cineasta cotidiano; filmando el país y un castillo; viviendo en el centro panamericano.
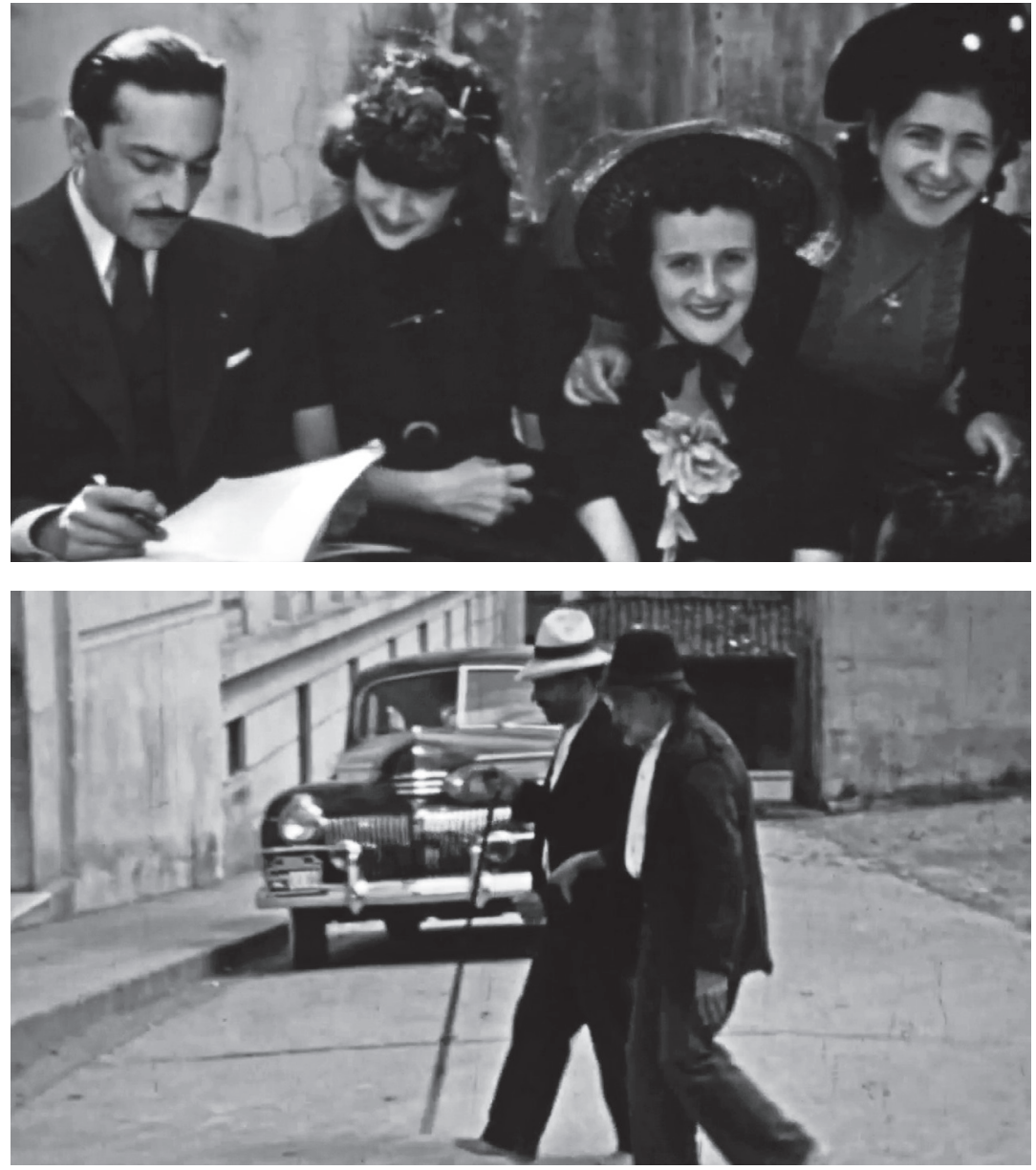

Figura 6. Gentes bogotanas. Fuente: Documental Cesó la Horrible Noche. 
Además de esos puntos, podemos encontrar una reflexión del director en torno a Roberto Restrepo: "Sus palabras me hablan de un intelectual decepcionado de su patria, sus imágenes, me revelan aún hombre que descubre a esos otros, a los que no viven en castillos, ni logran viajar al exterior”. Mientras escuchamos, vemos una escena muy interesante de Roberto, en claro oscuro, con su mirada fija mirando a través de una ventana, mientras gira su torso, y observa la cámara con una leve sonrisa. Presencia algunos registros de un grupo de personas que quieren entrar a un edificio, y un pequeño reten policial. Escúchanos la voz del presidente Mariano Ospina Pérez; así, muy entusiastas en una primera mirada creemos que hacen parte del momento cumbre de abril, pero descubrimos que simplemente hacen parte de las elecciones de 1946.

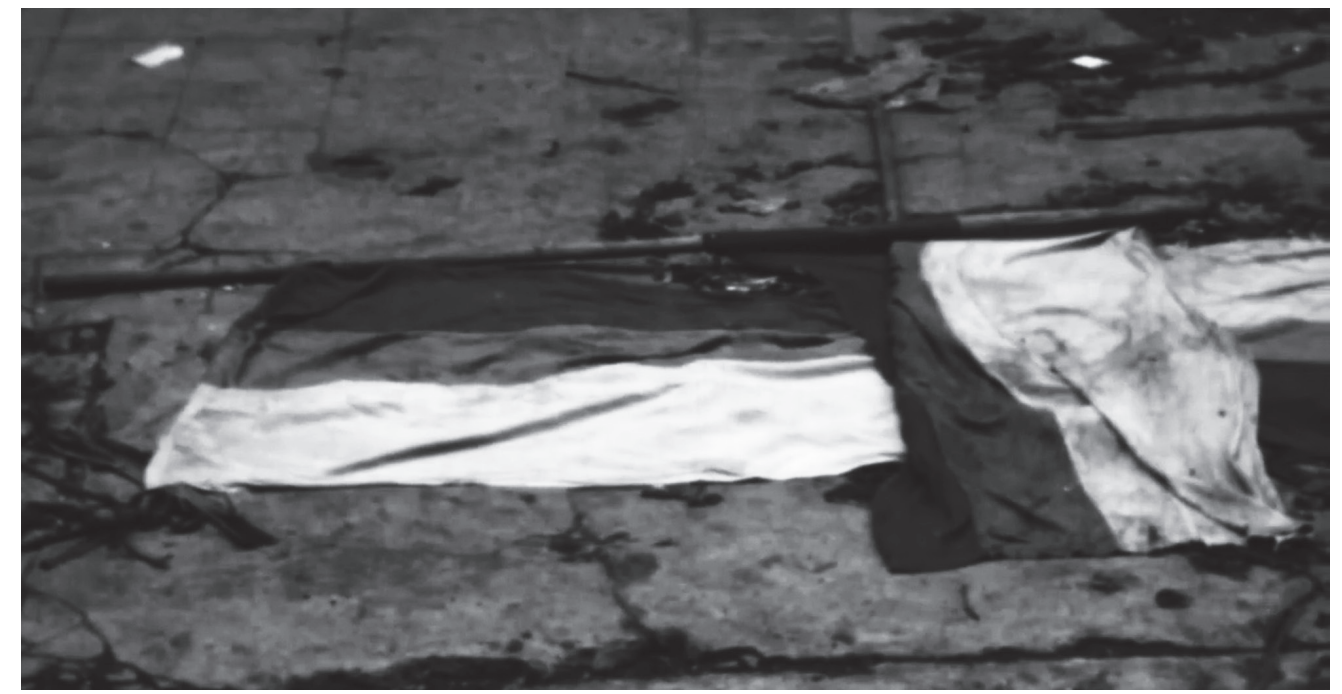

Figura 7. La bandera colombiana en el sitio del asesinato del caudillo liberal. Fuente: Documental Cesó la Horrible Noche.

Sobre las tensiones de 1948 tenemos las imágenes del 9 de abril, gente que va y viene, otros se dirigen con rumbo fijo, algunos policías montados en caballos, y otros enarbolando la bandera roja como si fueran al campo de batalla, un camión lleno de militares, una familia en el medio sin saber qué hacer; y luego, una imagen que se enfoca en la turba que parece va en dirección del palacio presidencial mientras escuchamos en la Radio Nacional de Colombia a un locutor que invita a lanzarse en contra del gobierno, a crear una revolución liberal. 


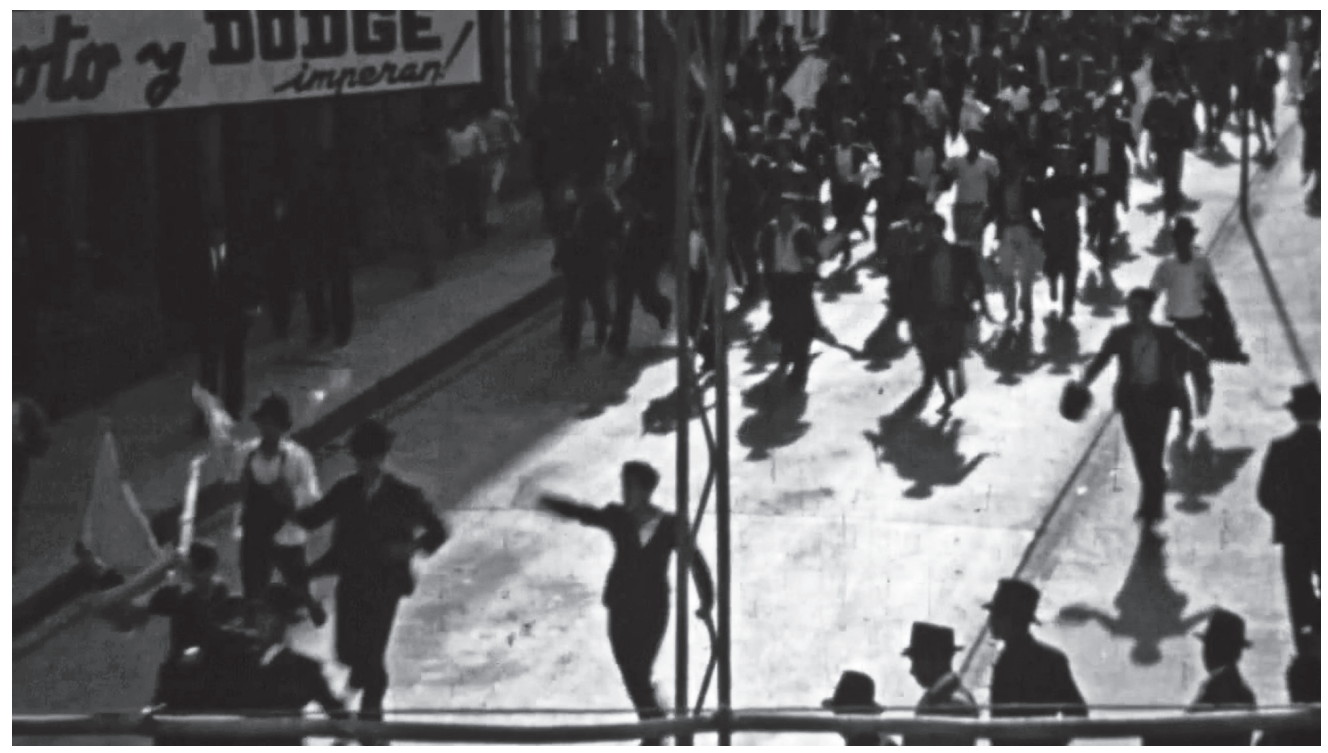

Figura 8. Pueblo en marcha. Fuente: Documental Cesó la Horrible Noche.

El montaje nos lleva entonces a observar el registro de un hombre en medio del bogotazo colorido que él vio y tomó, y que acá en forma de duelo, nosotros vemos en blanco y negro, con una transeúnte que pone su mirada sobre el foco, es atraída, y se inmiscuye en el rollo; vemos entonces los estragos de una ciudad saqueada, incendiada, y destruida en su zona céntrica, pasamos al color documental. Dos damas pasan frente a la cámara y se inscriben en el lente directo mientras el fondo es destrucción pura, tenemos entonces registros de la calle del Palacio de San Carlos, y gentes que inmersos en el contexto, parecen moverse de nuevo ante la cotidianidad de unos días después de El Bogotazo.

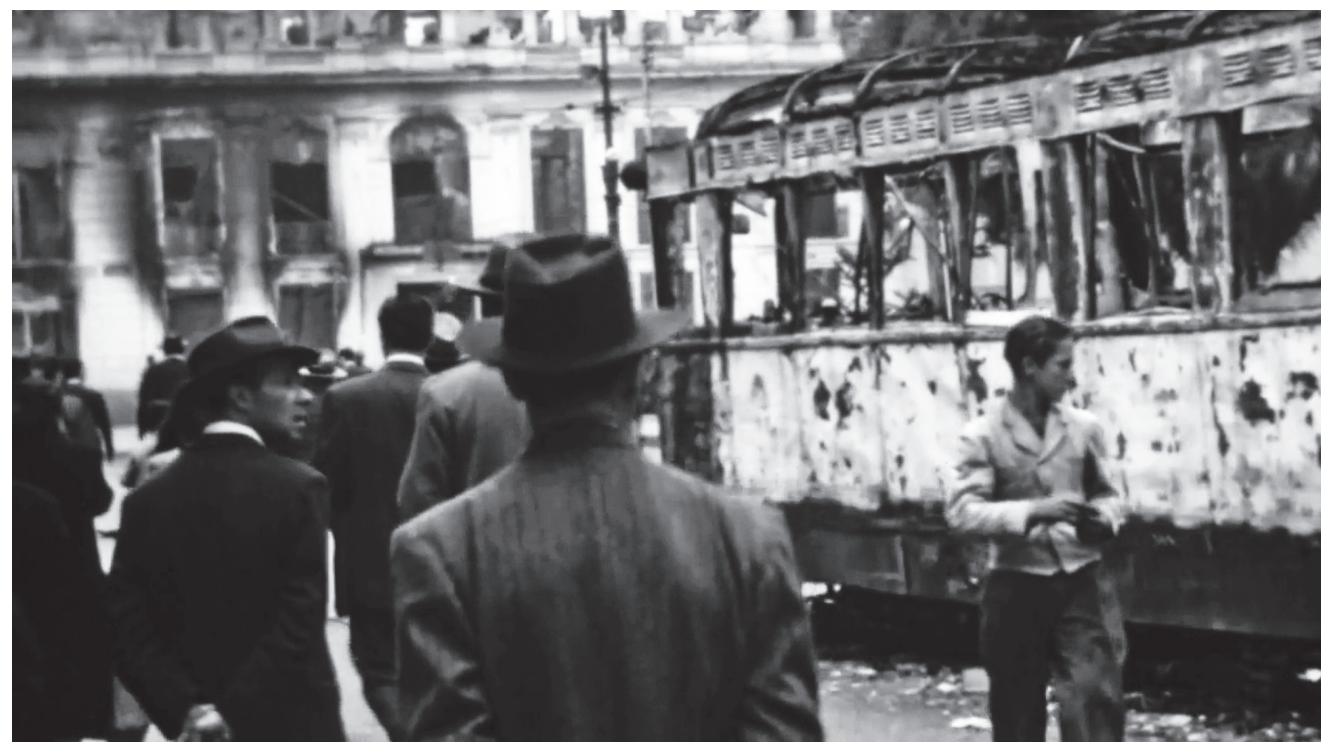

Figura 9. Estragos de El Bogotazo. Fuente: Documental Cesó la Horrible Noche. 
En medio de las “tomas del desastre", Roberto se detiene a filmar un hombre que lleva algo entre las manos, él, un poco esquivo, parece querer evitar el momento, pero queda integro, inclusive con cierta angustia que se disipa en sus ojos. Volvemos al blanco y negro, nuevas imágenes, desastres comunes, paneo significativo que muestra las calles que fueron testigo de la anarquía, y los muertos; nuevamente un transeúnte decide mirar al camarógrafo, sin quererlo, se vuelve un testigo implícito del testimonio de captar la realidad: mira, se detiene, se pierde.

En el epílogo de una jornada, representada en lo poco que observamos del El Bogotazo, los ciudadanos regresan al centro capitalino, son parte de la narración que "nos devuelve la película”, acción directa de reintegrarnos al pasado en una cinta casera llena de historia. ¿Punto de llegada?, las tres banderas pisoteadas y un congelamiento de la imagen con un militar y su fusil, metáfora directa de nuestro conflicto armado. Por lo tanto, vemos en las imágenes a esos bogotanos que parece se reintegran a la cotidianidad, un vaivén de gentes que sobrevivieron al sobresalto político; y allí, todavía un bogotano que se atreve nuevamente a mirar la cámara.

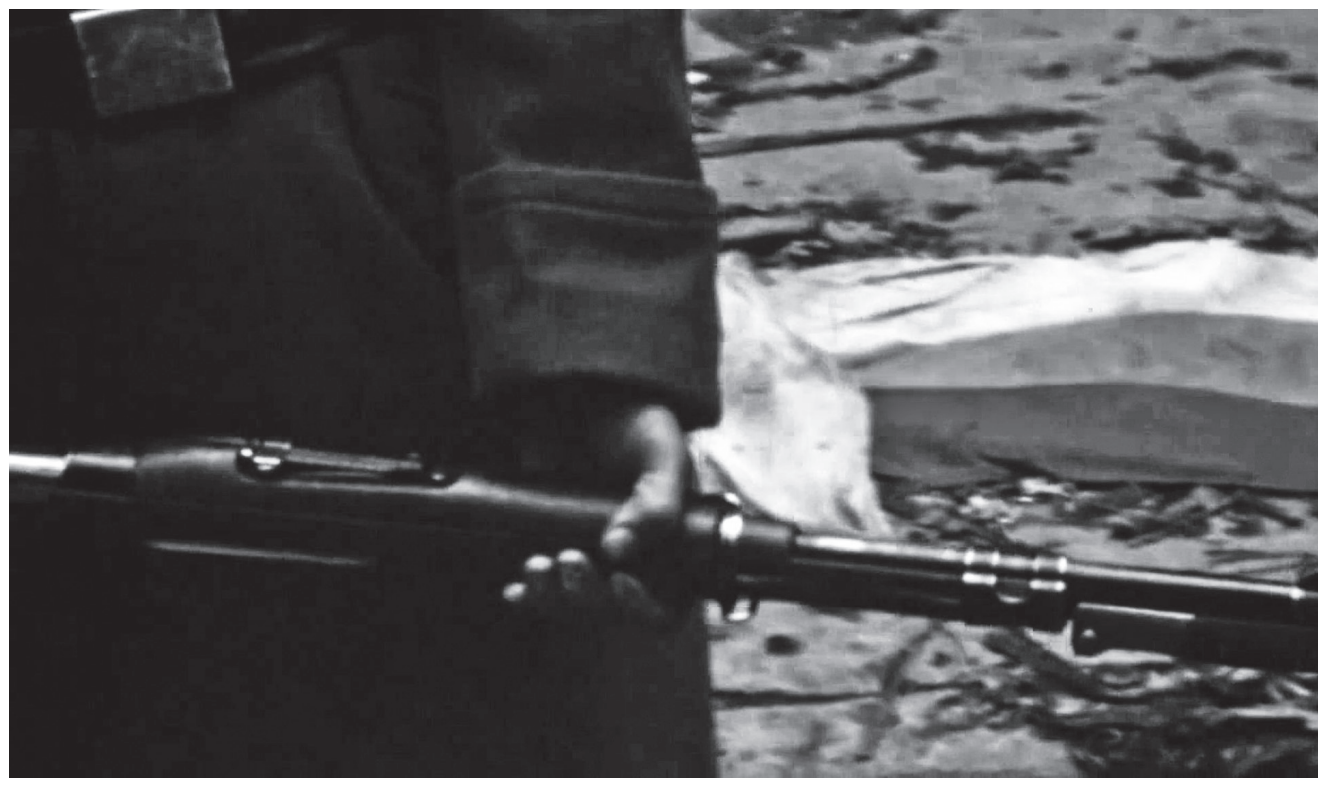

Figura 10. Militar y bandera. Fuente: Documental Cesó la Horrible Noche.

Sin lugar a dudas estamos ante un montaje de imágenes bien edificadas con base en un registro personal que valoró la ciudad como territorio, y en ella un acontecimiento del cual fue testigo Roberto Restrepo. Podríamos insinuar que en 1948 el cronista le dio un significado especial a sus registros fílmicos considerando su valor histórico; lo que le serviría igualmente como insumo para reflexionar y presentar sus escritos en el texto titulado Nueve de abril quiebre cultural y política, el mismo año del suceso.

La particular imagen de la bandera de Colombia en estado de indefensión, que observamos dos veces en Cesó la Horrible Noche, contrasta con otros fotogramas del cine nacional donde se expone de manera orgullosa como símbolo patriótico: 
-Inicialmente, en la única imagen que existe de la cinta de Francesco

Di Domenico, El Drama del 15 de Octubre (1915), observamos a una dama homenajeando a Rafael Uribe Uribe en el cementerio central de Bogotá junto a su busto, y empuñando en su mano derecha el asta con el pabellón tricolor.

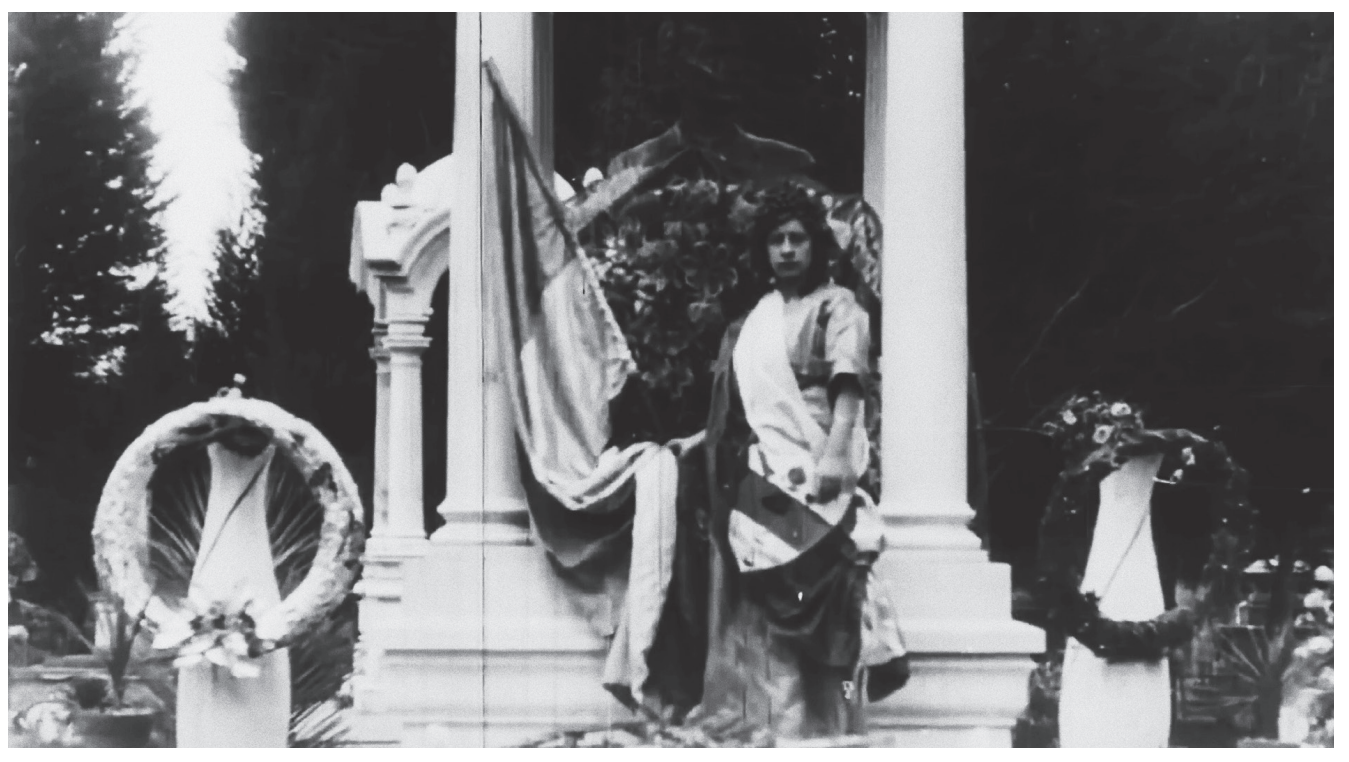

Figura 10. El Drama del 15 de Octubre-1915. Fuente: Fundación Patrimonio Fílmico Colombiano.

En María (1922) de Alfredo del Diestro y Máximo Calvo, del cual conservamos sólo 25 segundos, descubrimos que en el guión se presenta como entrada de su primer cuadro, la bandera nacional:

"Aparece flotando el pabellón colombiano y poco a poco va pareciendo en el centro de él el retrato de Jorge Isaacs”.

Con la película Garras de Oro (1927) de Jambrina, tenemos dos momentos relevantes en la exposición patriotera del símbolo: primero, cuando un intertítulo nos anuncia: " $\mathrm{Si}$ Uds. Los yanquilandeses conocieran la historia de Panamá, estoy seguro de que estarían todos con nosotros..., Ese día aciago para mi patria, la bandera que flotaba gloriosa en el istmo...,". Entrando la imagen de la bandera coloreada a mano, izada y ondeante; luego, otro letrero: “...fue arriada para siempre..., por manos vendidas..., por la garra de oro; más fuerte que el honor de los pueblos". Segundo, cuando la obra nos indica en su historia: "Hoy es 20 de julio, la fecha clásica de Colombia, y esa música es el himno nacional de mis hijos...”, apareciendo en escena dos infantes que desfilan felices en el salón mientras escuchan las notas del himno, y llevan en sus manos pequeñas banderas, encontrándonos con una imagen nacionalista. 


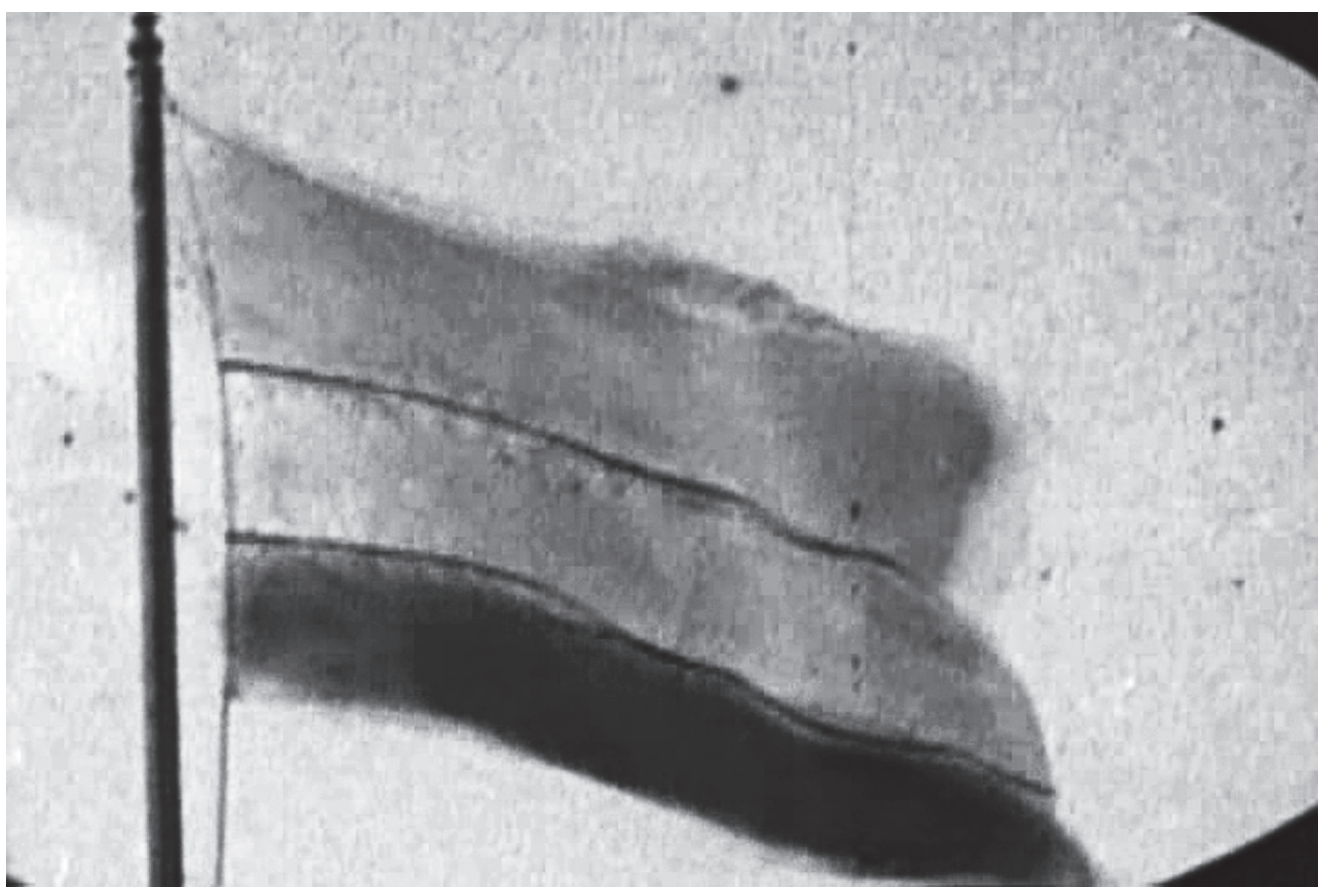

Figura 11. Garras de Oro -1927- Fuente: Fundación Patrimonio Fílmico Colombiano.

Por último, en el documental Colombia Victoriosa (1933) de los Hermanos Acevedo, vemos en algunas de sus escenas el uso que tiene la bandera como estandarte de manifestaciones en la ciudad, así como elemento de orgullo y valor en los escenarios que ellos adecuaron para representar el conflicto bélico con el Perú.

El pabellón, en la obra de Ricardo Restrepo, contiene un significado único de derrota, esconde tras de sí un mensaje de insatisfacción de aquellos que la enarbolaron en las manifestaciones del 9 de abril de 1948, y que finalmente las abandonaron en el sitio del atentado al caudillo, lo que correspondería a un fracaso del Estado en su vida social y cultural en momentos donde la capital colombiana representaba la viva imagen del panamericanismo a través de un evento que simplemente se adecuaba a las nuevas políticas del capitalismo norteamericano de postguerra.

Con respecto a los personajes anónimos que aparecen en el documental, y se atreven a "echarle un vistazo" al hombre detrás de la cámara y su centro de foco, debemos indicar que asumen en el montaje cierta relevancia distintiva que el director desea estimular; sin esperarlo, entramos en una fase de descubrimiento y asombro ante esos seres desconocidos que habitaron la capital, cada uno con una experiencia diferente ante el suceso histórico. Sin esperarlo, se asemeja a sus similares de Europa en documentos fílmicos observados sobre la Primera y Segunda Guerra Mundial titulados Apocalipsis ${ }^{8}$. Allí también algunos ciudadanos se inmiscuyen en el entorno de quienes filman, simplemente con sus miradas entran en la esfera de la eternidad cinematográfica que les posibilitó el camarógrafo de turno. 


\section{Conclusión}

Se ha presentado al lector una mirada particular del documental fílmico como ejercicio de memoria histórica, usando y editando archivos caseros en una obra relevante para la historia social y política de Colombia. Cesó la Horrible Noche entra en el rango de patrimonio audiovisual por su mensaje directo enfocado a recrear a través de la visión de un ciudadano colombiano aficionado al cine, algunos momentos significativos de la violencia partidista tan común en el Siglo XX.

Si atendemos la afirmación que "el documental debe reflejar los problemas y las realidades del presente. No puede derramar lágrimas sobre el pasado, y le resulta peligroso vaticinar el futuro" (Rotha, 1989, p.150), tendremos en los registros realizados por Roberto en 1948, y el trabajo de búsqueda, encuentro, organización, y montaje de Ricardo en el 2013, tres momentos intemporales por los cuales fue posible entender las mentalidades de la sociedad registrada. ¿Cómo entender los problemas del pasado, presente y futuro en Cesó la Horrible Noche? La respuesta vendría de las intervenciones que han tenido los materiales de archivo, de su puesta en escena, del paso silente al sonido, de su musicalización, y en definitiva por el guión que el director decidió poner en línea directa de comunicación con los escritos de su abuelo, los cuales marcan una distancia especial en el tiempo, pero parecen vigentes a la luz de los acontecimientos que la Historia de Colombia ha sobrellevado desde el 9 de abril.

Otro punto de enfoque relevante es ubicar el documental en los modos de la imagen que plantea José M. Català: 1. Función informativa de la imagen -la imagen constata una presencia-; 2. Función comunicativa de la imagen -la imagen establece una relación directa con el espectador o usuario-; 3. Función reflexiva de la imagen -la imagen propone ideas-; 4. Función emocional de la imagen -la imagen crea emociones(Catalá, 2008, p.p. 30-40). Sin profundizar sobre cada uno de los puntos que propone el autor, es notable que desde el lugar de espectador, historiador, aficionado al cine, o por el contario, simple observador casual, asumimos las etapas en el proceso de acercarnos a la obra, con la salvedad de interferir en ellas a través de nuestros gustos disciplinares y espacios de discusión. Por ejemplo: la presencia de una sociedad de medio siglo en el filme; la relación directa que tengo con su mensaje porque sé que sucedió el 9 de abril de 1948; las ideas que propone la obra y que descubro desde mi experticia; y las emociones que despiertan en mí algunos registros; suman al proceso individual de edición y montaje de un texto con ideas fijas de fuentes palpables a las cuales puedo acceder, observar, leer, criticar y entrelazar.

Ante las relaciones del cine con la educación, la historia, y la memoria, vemos en el documental Cesó la Horrible Noche otra fuente de estudio para entender nuestro pasado desde las mediaciones que nos da el presente; tenemos con las imágenes de Roberto Restrepo, un insumo discursivo que claramente puede ser usado como añadidura a las reflexiones que en un salón de clase escolar podemos hacer de la Historia de Colombia desde los aspectos culturales, económicos, políticos, y sociales: 
[...]El cine es un arte.Y es, sobre todo, un arte de la memoria, tanto colectiva como individual. Educar para el cine, en cierto sentido, es también interrogarse sobre los recuerdos transmitidos por las imágenes y los sonidos. Es volver a encontrar gestos y señales olvidados, descubrir rostros de antaño y un entorno que fue el nuestro o el de nuestros padres y antepasados. Es reencontrar el tiempo más allá de las imágenes que lo evocan. (Clarembeaux, 2010, p. 26)

Estamos ante un momento interesante de apropiación del conocimiento, el cual desde la educación podemos aprovechar para incluir el cine como apoyo positivo. El pasado a través de las imágenes documentales, de ficción o adaptación histórica, pasan indudablemente por el filtro efectivo de quien las usa; proceso que seguramente ante las condiciones de nuestro sistema escolar, difiere de forma significativa ante recursos técnicos, profesionales, y ante todo la negligencia del Estado en incentivar y modificar el sistema educativo colombiano, y allí, nuevamente la inclusión de la enseñanza de la historia como materia obligatoria.

Por último, en perspectiva del ejercicio realizado, con el insumo fílmico reseñado y condicionado desde la marca de la Historia del Cine Colombiano y su análisis, es importante resaltar el valor agregado que tiene el documental en el escenario colombiano de sus representaciones; "los filmes no son considerados ya como simples ventanas que dan al universo, constituyen uno de los instrumentos de que dispone una sociedad para ponerse en escena y mostrarse" (Sorlin, 1992, p. 252); así ocurre en el color documental de un filme que refleja la vida misma de una sociedad que vivió un hecho trascendental en una semana de abril hace 67 años.

\section{Notas}

${ }^{1}$ Licenciado en Historia, Universidad del Valle. Magister en Historia, Universidad Nacional de Colombia. Diplomado en Gestión del Patrimonio Audiovisual, Universidad de Bogotá Jorge Tadeo Lozano. Ganador en el año 2014 y 2010, de la Beca de Investigación en Cine; en el año 2008 realizó la pasantía en medios audiovisuales en la Fundación Patrimonio Fílmico Colombiano, las tres otorgadas por el Ministerio de Cultura. Organiza desde el año 2013 las Jornadas de Cine e Historia. Pertenece al grupo de investigación Nación-Cultura-Memoria, del Departamento de Historia de la Universidad del Valle. Actualmente se desempeña como profesor de Cine y Televisión en la Universidad Agustiniana.

${ }^{2}$ Este libro, cuyo sustento son fuentes orales, trae una serie de fotos del líder en sus momentos más trascendentales, así como aquellas que escenifican los acontecimientos desarrollados después de su muerte: Gaitán en pleno discurso; rodeado de gente del común y él en primer plano; una imagen de la marcha de las antorchas; con su maestro en derecho penal Enrico Ferri; Gaitán en la camilla de atención con su cuerpo inerte; la multitud enardecida; el tranvía incendiado; las filas de muertos amontonados en el cementerio central, entre otras imágenes. En las primeras ediciones de este texto no aparecen los créditos de quienes hicieron esas fotografías, sin embargo podemos decir que algunas corresponden a Luís Alberto Gaitán -Lunga-, Sady González y Manuel H Rodríguez.

${ }^{3}$ Reyes utilizó como fuentes los textos de Carlos Lleras Restrepo, De la República a la Dictadura; de Joaquín Estrada, El Nueve de Abril en Palacio, Horario de un Golpe de Estado; de Abelardo Forero B., Grandes Fechas; de Arturo Abella, Así Fue el nueve de Abril; además de la obra citada de Arturo Álape.

${ }^{4}$ Grupo político colombiano desaparecido. La sigla significa Alianza Nacional Popular, fundado en 1961 por Gustavo Rojas Pinilla. 
${ }^{5}$ Yamid Galindo Cardona, Documental (es): Reflexiones de un estilo narrativo, en el blog: http:// yamidencine-y-filo.blogspot.com.co/2015/07/documental-es-reflexiones-de-un-estilo.html, Historias en Cine-y-Filo publicado en julio 20 de 2015.

${ }^{6}$ Ricardo Restrepo, Cesó la Horrible Noche (Los Archivos de mi abuelo), Bogoshorts Tv, la información ha sido editada para el texto. Tomado de: https: / / www. youtube.com/watch?v=DrJQWlcxvEY Igualmente encontramos en este ejercicio del festival de cortos la reflexión de Enrico Mandirola sobre el proceso de digitalización, y el sonido, teniendo en cuenta que los materiales originales son mudos.

${ }^{7}$ Ricardo Restrepo, Dir. Cesó la Horrible Noche, Canal Ficci Channel. Festival Internacional de Cine de Cartagena. Tomado de: https://www.youtube.com/watch?v=9Qo2SOMhXY8.

${ }^{8}$ Producidos por National Geographic.

\section{Referencias}

Álape, A. (1987), El Bogotazo: Memorias del Olvido. Bogotá, Colombia: Editorial Planeta.

Aumont, M. (2006), Diccionario Teórico y Crítico del Cine. Buenos Aires, Argentina: La marca Editora.

Barnouw, E. (2005), El Documental Historia y Estilo. España: Editorial Gedisa

Burke, P. (2005), Visto y noVisto. Barcelona, España: Crítica.

Catalá, J.M. (2008), La Forma de lo Real. Barcelona, España: Editorial UOC.

Clarembeaux, M. (2010), Educación en Cine: Memoria y patrimonio. Huelva, España: Comunicar, nº 35, v. XVIII, Revista

Científica de Educomunicación.

Didi-Huberman, G. (2006), Ante el Tiempo Historia del arte y anacronismo de las imágenes. Argentina: Adriana Hidalgo editora S.A.

Ferro, M. (1980), Cine e Historia, Barcelona, España: Editorial Gustavo Gili, S.A.

Martínez, H. (1978), Historia del Cine Colombiano. Bogotá, Colombia: Librería y Editorial América Latina.

Ricoeur, P. (2010), La Memoria, la Historia, el Olvido. Argentina: Fondo de Cultura Económica.

Rotha, P. (1989), Los problemas y las Realidades del Presente, En El Documental y sus Modalidades, Textos y Manifiestos del Cine, Eds. Joaquim Romaguera I Ramio, Homero Alsina Thevenet, Catedra, Barcelona.

Sánchez, I. (1987), Cine de laViolencia. Bogotá, Colombia: Ediciones de la Universidad nacional de Colombia.

Sorlin, P. (1992), Sociología del Cine. México: Fondo de Cultura Económica.

\section{Webgrafía}

Cesó la Horrible Noche de Ricardo Restrepo (Los archivos de mi abuelo) (2015),

https: / /www.youtube.com/watch?v=DrJQWlcxvEY,

Galindo, Y. (2015), Documental (es): Reflexiones de un estilo narrativo, http: / yamidencine-y-filo.blogspot.com.co/2015/07/ documental-es-reflexiones-de-un-estilo.html

(2011), El Bogotazo en Imágenes, en el blog: http://yamidencine-y-filo.blogspot.com.co/2011/04/el-

bogotazo-en-imagenes_09.html

Restrepo R. Dir. Cesó la Horrible Noche, (2014), Canal Ficci Channel, https://www.youtube.com/watch?v=9Qo2SOMhXY8

Zuluaga, P. (2015), Documental colombiano reciente: mapas, fronteras y territorios,

http: / / pajareradelmedio.blogspot.com.co/2015/12/documental-colombiano-reciente-mapas.html

\section{Ficha Técnica}

\section{Cesó la Horrible Noche}

País: Colombia. Año: 2013. Dirección: Ricardo Restrepo.

Producción: Patricia Ayala / Pathos Audiovisual.

Dirección de fotografía: Roberto Restrepo y Ricardo Restrepo

Género: Documental.

Recibido: septiembre de 2015 / Aprobado: mayo 30 de 2016 